\section{Posmituha A., \\ Kravets $\mathbf{5}$. Suponyev V., Kulazhenko $\mathbf{Y}$.}

\title{
DETERMINATION OF THE SIZE OF THE SEAL ZONE AND THE SOIL PRESSURE ON UNDERGROUND COMMUNICATIONS IN THE PROCESS OF SOIL DEFORMATION BY THE WEDEE-SHAPED TIP
}

\begin{abstract}
Об’єктом дослідження є робочий орган з клиновим наконечником для статичного проколу грунту з одночасним прокладанням декількох футлярів під підземні комунікачї комунального господарства. Одними з проблемних місиь, що потребують дослідження, є прокладання, розташування та сусідство різних видів підземних комунікацій, прокладених безтраншейним способом. Вивчення зони впливу робочих органів на грунт та комунікацї дасть можливість більш якісно проектувати використання підземного простору, знизити ризики пошкодження або руйнування комунікаиій та знизити вартість робіт. Дослідження базуються на основі закону збереження маси до і після ущільнення грунту клиновим наконечником та на основних теоріях механіки грунтів. Це дає змогу визначити тиск грунту на робочий орган та на комунікацї, що розташовані поруч. Отриманий в роботі результат показує, що величина тиску не однакова в різних напрямках клинового робочого органу. Також в роботі доведено, що кількість футлярів, які одночасно прокладаються, мало впливають на зону пружно-пластичних деформацій грунту. Ці ефекти роблять таку форму отвору незамінною при необхідності одночасного прокладання декількох, більше 3 , футлярів, у порівнянні з традиційним конічно-циліндричним наконечником. Слід відмітити, що для визначення тиску грунту на підземні комунікації були використані лише розміри робочих органів, та дані, які легко визначити - тип та щільність грунту, вологість, пористість та решта стандартизованих характеристик. Використання даного методу має суттєву перевагу над іншими методами, що містять в своїи основі емпіричні залежності, які або важко визначити, або їхня достовірність викликає сумніви. Завдяки зменшенню площі поперечного перетину грунту, що деформується, клиновий робочий орган є незамінним для протягування групи футлярів.
\end{abstract}

Ключові слова: безтраншейна технологія, статичний прокол грунту, зона ущільнення, тиск грунту, інженерні комунікащіі.

\section{Introduction}

High competition in the field of urban planning forces engineers to create new machines for construction work, which will reduce the cost of work, reduce the cost and duration of work, reduce the impact on urban infrastructure and city residents. The use of progressive working bodies will allow competing in the market of services. The new form of the working body will allow to determine the amount of pressure on underground communications, to know the direction and zone of the dangerous neighborhood.

Modern requirements dictate the need for the simultaneous installation of several protective cases in the form of pipe-cases in the amount of up to 8 or more. Traditionally, a well is formed of a round shape by a working body with a conical tip. Lining of cases in this case is carried out in the form of a bundle of several separate elements stretched into one hole. Accordingly, the larger the diameter of the well, the greater the likelihood of damage to the road base or adjacent communications, requires a significant increase in the distance to them. Single-row pipe wedge-shaped tip, which must be used in this case, allows to change and control the sealing zone and its impact on objects located close to the array of soil.

Thus, the search for ways to improve the technology of static soil puncture for laying linearly extended objects (LEO) is an important task. When developing technical solutions, it is necessary to take into account the need to simultaneously lay several pipelines and the pressure of the deformed soil on nearby communications.

\section{The object of research and its technological audit}

The object of research is a working body with a wedgeshaped tip for static puncture of the soil with the simultaneous laying of several cases. The lack of analytical calculations of the forces of influence of soil pressure from the advancement of the wedge-shaped tip makes it impossible to carry out its comparative analysis with the traditional method of obtaining a round well.

The resistance to the movement of the cylindrical working body is determined by the parameters of the working body and the properties of the compacted soil, described by the authors in [1-3].

Resistance to the advancement of the working body is determined by the parameters of the working body and the properties of the compacted soil.

The parameters of the wedge-shaped tip (Fig. 1) are determined by the diameter of the shells (protective tubes, in which communications are then drawn), which must be freely drawn into the cavity and their number. 


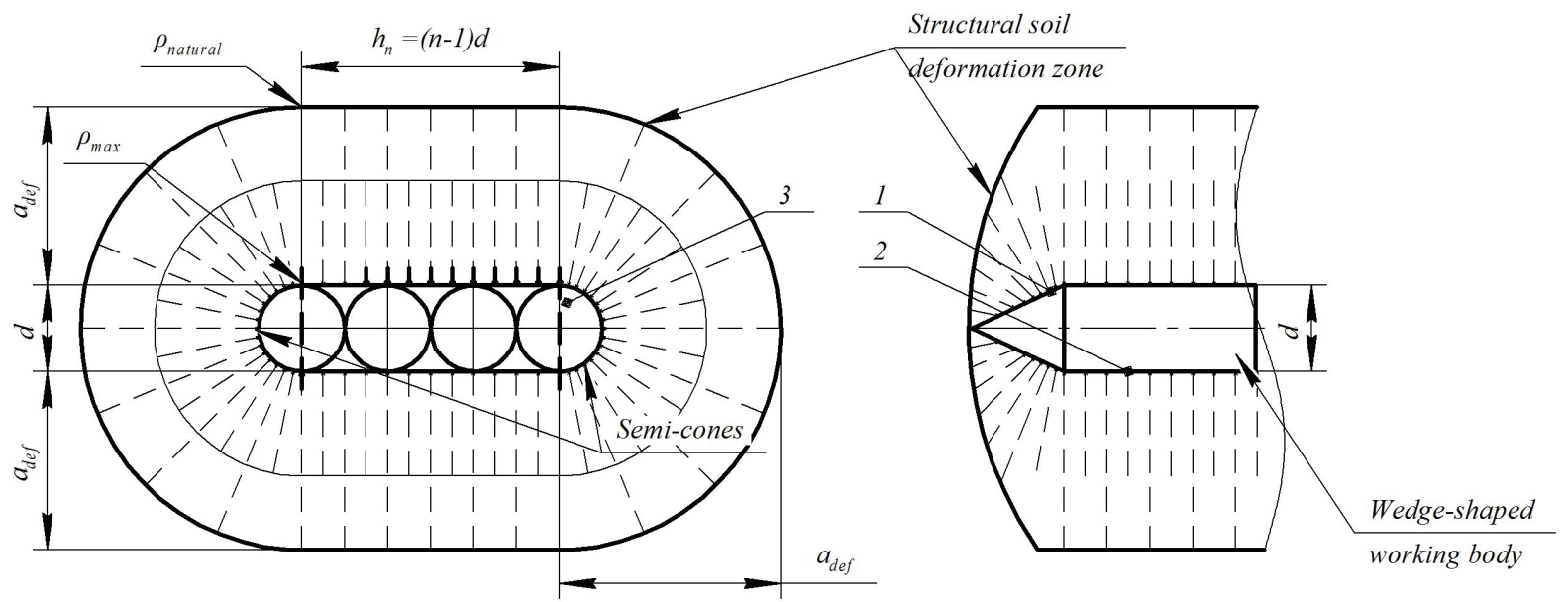

Fig. 1. The location of the working body in the soil and the zone of deformation, as well as overpressure: 1 - a wedge-shaped part of the working body; 2 - a flat guide with semicircular edges; 3 - cases

In conditions of dense urban development and a large number of engineering networks located under the surface, the use of a wedge knife will, under practical conditions, significantly improve the efficiency of trenchless laying of underground utilities. An increase in the number of shells, laid simultaneously, does not lead to an increase in the zone of influence and pressure on adjacent communications from soil compaction.

One of the problem areas requiring research is the laying, location and proximity of various types of underground communications, laid in a trenchless way. The study of the zone of influence of working bodies on the soil and communications will provide an opportunity to better design the use of underground space, reduce the risks of damage or destruction of communications and reduce the cost of work.

\section{The aim and objectives of research}

The aim of research is improvement of the technology of static soil puncture by simultaneously laying engineering communications with a working body with a wedge-shaped tip. This will improve the quality of work and reduce energy costs of the process.

To achieve this aim it is necessary:

1. To obtain a theoretical method for determining the pressure of the soil, while moving the wedge working body.

2. To determine the law of soil density variation over the tip thickness and establish the soil pressure on the underground utilities falling within the range of elasticplastic deformations.

3. To study the influence of the size of the working body and the properties of the soil, and its pressure on adjacent communications.

\section{Research of existing solutions of the problem}

The main directions of development of trenchless technologies of laying communications in the world are horizontal directional drilling and microtunnelling in the form of a static puncture with soil evacuation. In the resources of the world scientific periodicals, the works [4, 5] can be highlighted, where the active methods of trenchless technologies are considered, but they pay little attention to the static puncture.
Studies $[5,6]$ are devoted to the selection and justification of the choice of the method of performing work, with a detailed analysis of the advantages and disadvantages of various technologies. And in works [7, 8] special attention is paid to trenchless technologies of construction and repair of long pipelines. It should also be noted studies [6], which is dedicated to the choice of the method and planning the implementation of particularly important work performed by the trenchless method.

In [9], the possibilities of expanding trenchless technologies to the size of microtunnelling and ways and options for work are described.

The work [10] turned out to be interesting, where they determined the influence of the soil and the communications located above them on the pipes laid at a certain depth. But in this work the question of the possibility of additional laying of pipes side by side, and the influence of the working bodies on them, is not at all displayed.

Much attention is paid to field testing and the calculation of axial efforts for laying communications using the trenchless method in works [11, 12], but none of the authors of these works pay sufficient attention to the static puncture.

Separately, let's highlight studies of the possibility of introducing trenchless technologies in hard soils [13] or in soils of categories 4-5.

Scientists who are engaged in solving the problem of trenchless laying of underground utilities with minimal energy consumption have devoted a lot of research in recent years. Thus, in works [2, 14], much attention is paid to puncture the soil over short distances up to $50 \mathrm{~m}$. The study of the process of static soil puncture and its stresses around the working body during the formation of a well is reflected in [15].

The nature of the process of deep cutting of soils with knife working bodies when laying cables and drains in the zone of supercritical cutting depth has a general character of interaction with the soil with a wedge-shaped tip [16, 17]. The last character is compacted soil in both sides of the wedge-shaped knife tip. This can be the basis for studying the processes occurring during the advancement of the wedge working body in the soil. But it does not fully reflect the specifics of the process of single-row laying of several cases at the same time and gives a fuzzy answer about the effect of deformed soil on nearby communications during cavity formation. 
Thus, the results of literary analysis allow to conclude that the process of puncturing the soil working body in the form of a wedge-shaped tip has not previously been studied.

\section{Methods of research}

From work [3] it is known that the puncture of the soil with a wedge-shaped tip can be effective within the borehole diameter, which is obtained from the condition of optimal resistance. So, it is found that the maximum reduction in resistance to puncturing takes place:

- for hard sandy loam with diameters $D=0.2 \ldots 0.25 \mathrm{~m}$;

- for semi-hard loam with diameters $D=0.13 \ldots 0.17 \mathrm{~m}$;

- for refractory clay with diameters $D=0.12 \ldots 0.13 \mathrm{~m}$.

It is obvious that after the same cavity the number of laying of pipes is limited, especially paying attention to the fact that their diameters are at least $100 \mathrm{~mm}$.

The study of the process of puncture of the soil working body with a wedge-shaped tip is quite time-consuming and expensive process. Therefore, the theoretical substantiation of the prospects for the introduction of a wedge-shaped knife with the trenchless laying of underground utilities and ideas about the patterns of the puncture process by the proposed working body will allow to determine the further technical improvement of the development and planning of its experimental research.

The calculated dependences are obtained by the integrated and differentiated countable equations, reflecting the mathematical model of the process of moving the working body in the soil.

The studies are based on the basic principles of the theory of soil mechanics and their cutting.

Based on the law of mass conservation before and after soil compaction with a wedge-shaped tip, let's have a scheme for determining the resistance of a wedge-shaped tip (Fig. 2):

$$
\left(a_{\text {def }}+\frac{d}{2}\right)(n-1) d \rho_{\text {natural }}=(n-1) d \int_{0}^{a_{y}} \rho_{x} d x,
$$

where $a_{\text {def }}-$ distance over which the soil is deformed by the wedge-shaped tip; $d$ - diameter of a linearly extended LEO object; $n$ - the number of simultaneously laid LEO; $\rho_{\text {natural }}$ - the natural density of the soil; $\rho_{x}$ - the pattern of change in the density of the soil in the deformed zone.

In the first approximation, the pattern of density change $\rho_{x}$ can be taken linear depending on the distance to the side wall of the hole [16] (Fig. 2).

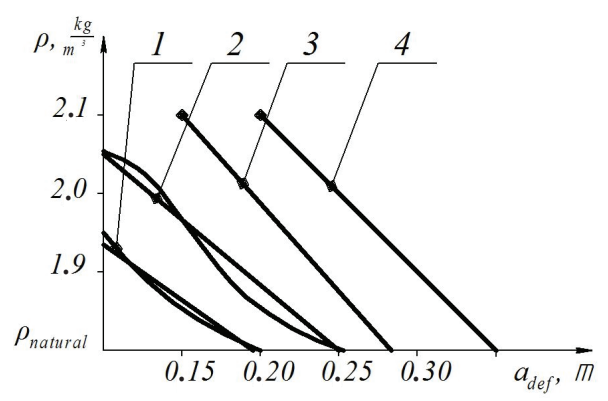

Fig. 2. The pattern of changes in the density of the soil in the deformed zone depending on the size of the hole [17]: 1 - a case with a size of $0.13 \mathrm{~m} ; 2$ - case size of $0.19 \mathrm{~m}$;

3 - case size of $0.245 \mathrm{~m} ; 4$ - case size of $0.325 \mathrm{~m}$
The adopted pattern of density changes is shown in Fig. 3:

$$
\rho_{x}=\rho_{\text {natural }}+\left(1-\frac{x}{a_{\text {def }}}\right)\left(\rho_{\max }-\rho_{\text {natural }}\right),
$$

where $\rho_{\max }-$ the maximum soil density in the side wall of the hole.

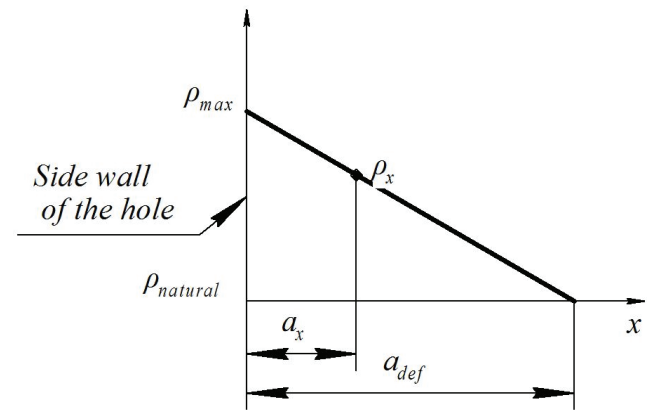

Fig. 3. Accepted pattern of changes in soil density

Taking into account (1), equality (2) will be rewritten in the form:

$$
\begin{aligned}
& \left(a_{\text {def }}+\frac{d}{2}\right) \rho_{\text {natural }}= \\
& =\int_{0}^{a_{\text {def }}}\left[\rho_{\text {natural }}+\left(1-\frac{x}{a_{\text {def }}}\right)\left(\rho_{\max }-\rho_{\text {natural }}\right)\right] \mathrm{d} x= \\
& =\rho_{\text {natural }} a_{\text {def }}+\left(\rho_{\max }-\rho_{\text {natural }}\right) a_{\text {def }}-\left(\rho_{\max }-\rho_{\text {natural }}\right) \frac{a_{\text {def }}}{2}= \\
& =\frac{\rho_{\text {max }}+\rho_{\text {natural }}}{2} a_{\text {def }} .
\end{aligned}
$$

The average density $\frac{\rho_{\max }+\rho_{\text {natural }}}{2}=\rho_{a v}$ after soil compaction is determined in [1]:

$$
\rho_{a v}=\frac{\rho_{\text {natural }}}{1-1 / \lambda^{2}}
$$

where $\lambda$ - characterizes the size of the zone of elastic-plastic deformations of the soil and depends on the type of soil and the depth at which the deformations are carried out:

$$
\lambda=\frac{\left(\gamma_{g r} h+\frac{c}{\operatorname{tg} \varphi_{0}}\right) \operatorname{tg}^{4}\left(\frac{\pi}{4}+\frac{\varphi_{0}}{2}\right)}{\sigma_{1}},
$$

where $\gamma_{g r}$ - the specific gravity of the earth; $h$ - the depth at which the puncture is carried out; $c$ - soil adhesion coefficient; $\varphi_{0}-$ the angle of internal friction of the soil; $\sigma_{1}-$ stress at the border of elastic and plastic zones of soil deformation [1]:

$$
\sigma_{1}=\frac{-B \pm \sqrt{B^{2}+4 A C}}{2 A}=\left|\frac{B+\sqrt{B^{2}+4 A C}}{2 A}\right|,
$$

where

$$
\left\{\begin{array}{l}
A=\sin \varphi_{0}\left(3-\sin \varphi_{0}\right), \\
B=3 c \cos \varphi_{0}-2.5 c \sin 2 \varphi_{0}+\gamma_{g r} h\left(1+\sin \varphi_{0}\right), \\
C=\left[\gamma_{g r} h\left(1+\sin \varphi_{0}\right)+4 c \cos \varphi_{0}\right] c \cos \varphi_{0} .
\end{array}\right.
$$


If substitute dependencies (4) and (5) into the equation:

$$
\begin{aligned}
& a_{\text {def }}=\left(\lambda^{2}-1\right) \frac{d}{2}= \\
& =\left[\frac{\left(\gamma_{\text {natural }} h+\frac{c}{\operatorname{tg} \varphi_{0}}\right)^{2} \operatorname{tg}^{8}\left(\frac{\pi}{4}+\frac{\varphi_{0}}{2}\right)}{\sigma_{1}^{2}}-1\right] \frac{d}{2} .
\end{aligned}
$$

For an ideal free flowing environment in which there is no adhesion $(c=0-$ sand $)$ :

$$
a_{d e f}=\left[\frac{\operatorname{tg}^{8}\left(\frac{\pi}{4}+\frac{\varphi_{0}}{2}\right)}{\left(1+\sin \varphi_{0}\right)^{2}} \cdot \sin ^{2} \varphi_{0}\left(3-\sin \varphi_{0}\right)^{2}-1\right] \frac{d}{2} .
$$

For a weightless connected environment $(\gamma h=0, c \neq 0)$ :

$$
a_{\text {def }}=\left[\frac{\frac{c^{2}}{\operatorname{tg}^{2} \varphi_{0}} \operatorname{tg}^{8}\left(\frac{\pi}{4}+\varphi_{0}\right)}{\sigma_{1}^{2}}-1\right] \frac{d}{2} .
$$

If accept that $\lambda=5.4 \ldots 6.0-$ for hard sand; $\lambda=4.3 \ldots 4.8-$ for semi-hard loam; $\lambda=4.0 \ldots 4.3$ - for refractory clay [1], then the average density of the soil in the elastic-plastic zone is equal to:

- for hard sandy loam $-\rho_{a v}=(1.03 \ldots 1.04) \rho_{\text {natural }}$;

- for semi-hard loam $-\rho_{a v}=(1.05 \ldots 1.06) \rho_{\text {natural }}$;

- for refractory clay $-\rho_{a v}=(1.06 \ldots 1.07) \rho_{\text {natural }}$.

According to the experimental data of production tests of trenchless draining plants, which work with the formation of supercritical zones [17].
For a reduced average density of soils, the size of the zone of their deformation is:

- for hard sandy loam $-a_{d e f}=(14.0 \ldots 17.5) d$;

- for semi-hard loam $-a_{d e f}=(8.7 \ldots 11.0) d$;

- for refractory clay $-a_{d e f}=(7.5 \ldots 8.7) d$.

\section{Research results}

Let's determine the pressure of the soil on underground utilities that fall within the zone of action of elastic-plastic deformations:

$$
\begin{aligned}
& q_{x}=\frac{1+\omega}{c_{c}} \rho_{h}\left(\frac{1}{\rho_{\text {natural }}}-\frac{1}{\rho_{x}}\right)= \\
& =\frac{(1+\omega) \rho_{h}}{c_{c} \rho_{\text {natural }}}\left[1-\frac{1}{\left.1+\left(1-\frac{x}{a_{\text {def }}}\right) \frac{\rho_{\max }-\rho_{\text {natural }}}{\rho_{\text {natural }}}\right]}\right]= \\
& =\frac{(1+\omega) \rho_{h}}{c_{c} \rho_{\text {natural }}}\left[1-\frac{1}{1+\left(1-\frac{x}{a_{\text {def }}}\right)\left(\frac{\rho_{\max }}{\rho_{\text {natural }}}-1\right)}\right]= \\
& =E_{g r}\left[1-\frac{1}{1+\left(1-\frac{x}{a_{\text {def }}}\right)\left(\frac{\lambda^{2}+1}{\lambda^{2}-1}\right)}\right],
\end{aligned}
$$

where $c_{c}-$ the soil compression ratio $\left(c_{c}=0.07 \ldots 0.09 \times\right.$ $\left.\times\left(\omega_{y}-10\right) \mathrm{MPa}^{-1}\right)[5] ; \omega$ - natural soil moisture; $\omega_{T}$ - yield strength of the soil; $E_{g r}=\frac{(1+\omega) \rho_{h}}{c_{c} \rho_{\text {natural }}}-$ compression modulus of soil deformation [2, 3].

Graphs $q_{x}$ are plotted as a function of the distance $x$ from the lateral face of the wedge for hard sandy loam, semi-hard loam, and refractory clay (Fig. 4).
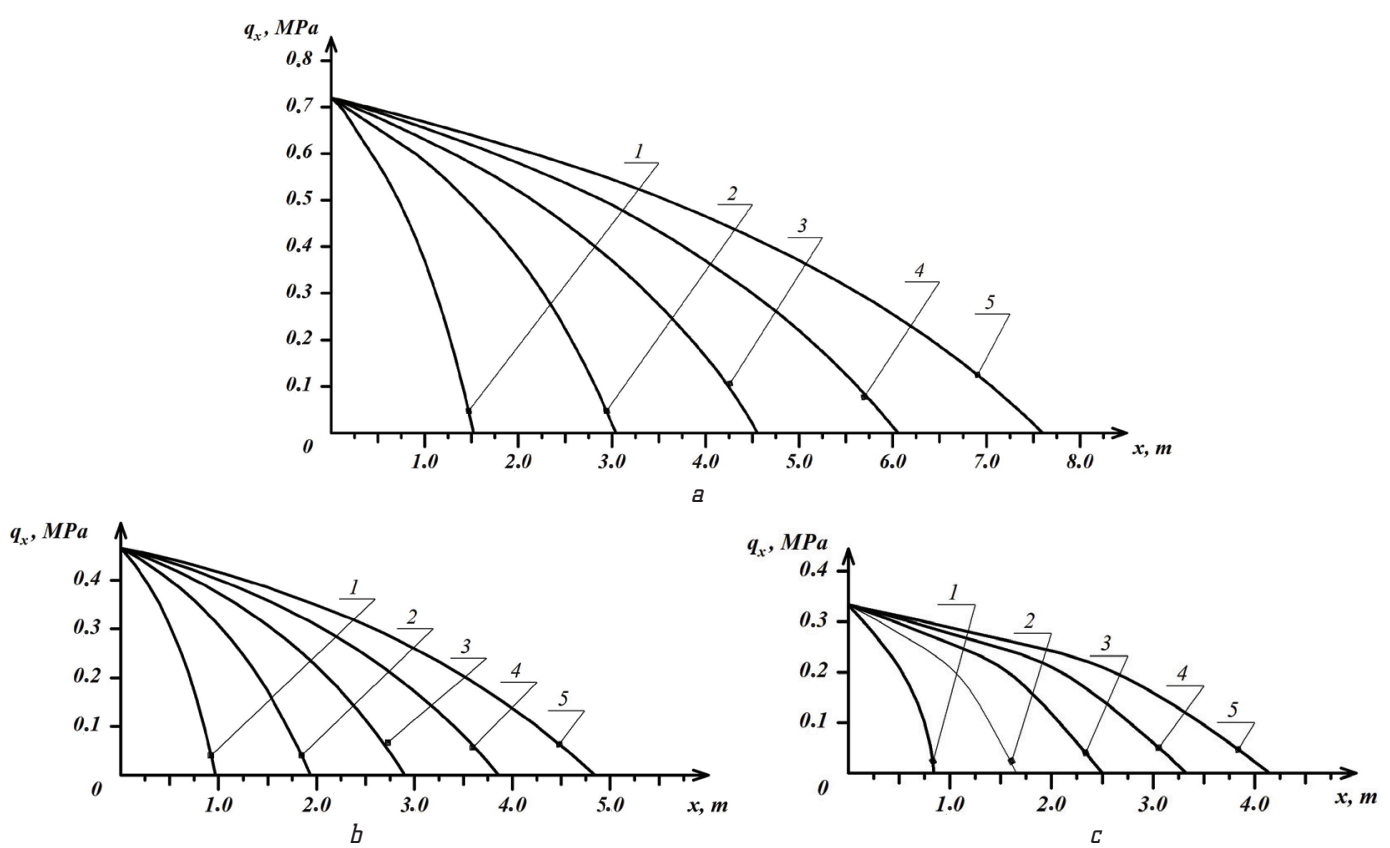

Fig. 4. Dependence of sail pressure on underground utilities on the distance, diameter, number of cases and the shape of the working body $n=5$ pcs., $h=1.5 \mathrm{~m}$ : $a$ - hard sandy loam; $b$ - semi-hard loam; $c$ - refractory clay: $1,2,3,4,5-$ wedge flat working body of the diameter of the case, respectively, 100, 200, 300, 400 and $500 \mathrm{~mm}$ 
For the construction let's take for both working bodies $[1-3]$ :

- the number of identical cases, laid at the same time $n=5$ pieces;

- the depth of laying communications $h=1.5 \mathrm{~m}$;

- the diameter of the cases 100, 200, 300, 400 and $500 \mathrm{~mm}$;

- characteristics of hard y loam $-E_{g r}=1.39 \mathrm{MPa}$,

$\lambda=5.6, \quad a_{d e f}=15.2 d$;

- characteristics of semi-hard loam $-E_{g r}=0.892 \mathrm{MPa}$,

$\lambda=4.5, a_{\text {def }}=9.63 d$;

- characteristics of refractory clay $-E_{g r}=0.631 \mathrm{MPa}$, $\lambda=4.2, a_{d e f}=8.32 d$.

Fig. 4 clearly shows that the use of the investigated working body substantially depends on the size of the case and is limited by the laying depth. Shallow depth will lead to the twisting of the soil surface.

\section{SWOT analysis of research results}

Strengths. Among the strengths of this study, it is necessary to note the obtaining of a theoretical definition of the soil compaction zone for underground utilities during its deformation with a wedge-shaped tip. Due to this, the possibility of a comprehensive assessment of the new technology of laying underground communications with the use of a static puncture of the soil by a working body with a wedge working body is obtained. The criterion for comparison of the proposed working body on the wedge-shaped tip with a traditional tip in the form of a cone is the force of resistance of the soil to their progress. Such a comparison makes it possible to obtain evidence in favor of a wedge-shaped tip. The obtained calculations of the forces of resistance of the puncture soil also make it possible to determine the power parameters of the installation and its design features. Determination of pressure from elastically plastic deformations to nearby communications, depending on the parameters of the working body and soil properties, makes it possible to estimate how close to nearby communications a puncture can be performed by the working body using the proposed tip.

Weaknesses. The weaknesses of this research are connected with the circumstances that theoretical solutions for determining the technological features of a soil puncture by a working body with a wedge-shaped tip did not receive experimental confirmation of some provisions. Author's assertions are based on the comparison of ideas from similar studies carried out with the blade working bodies of machines for deep laying of underground utilities.

Opportunities. Additional research opportunities are improving the quality and reducing the costs when performing work for trenchless laying of utilities. This follows from the fact that the compaction of the soil around the cavity is constant, regardless of the number of laid pipes. And this, in turn, makes it possible to get closer to the surface of roads, without destroying its base. The same is important when laying communications close to other underground structures and adjacent communications. The laying of several pipelines through a traditional well of the cylindrical form does not have such an opportunity. In addition, the use of a wedge-shaped tip provides significant savings in energy consumption, due to less resistance to puncture soil with a similar number of laid pipelines.

Threats. At this stage, experimental studies of soil pressure on neighboring communications in various directions relative to the working body have not yet been completed. There have been no studies on the use of this working body in soils, they are little compressed. Even theoretical studies on changing the position of the working body in the process of pulling are absent.

Thus, a SWOT analysis of the research results determines the priorities for further research:

- to study the effect of solid inclusions on the trajectory of the working body;

- to study the effect of soil moisture on its pressure on nearby communications;

- to consider the possibility of using this working body for the repair of pipelines.

\section{Conclusions}

1. It is established that the simultaneous laying of several pipelines is more efficiently laid by installations of static action with a working body, in which the tip has a wedge shape. Calculations found that the resistance of the soil in single-row laying of pipelines by a working body with a wedge-shaped tip, compared to traditional laying of several pipelines with one beam through a well with a round hole, is less by:

- $50 \%$ when laying 2 cases;

- $31 \%$ when laying 3 cases;

- $20 \%$ when laying 4 cases;

- $19 \%$ when laying 5 cases;

- $44 \%$ when laying 10 cases.

2. The law of change in the density of the soil over the thickness of the tip is determined, and the pressure of the soil on the underground utilities that fall within the zone of action of elastic-plastic deformations is established. According to the received schedules, the minimum depth of laying communications is determined. It should be noted almost linear dependence of the pressure change from the maximum to the natural thickness of the working body.

3. The cross-sectional shape of the hole is considered and the analytical dependence of the soil pressure on the working body on the shape and number of linearly extended objects is created simultaneously. The obtained dependences allow to assert that with such a hole, depending on the number of communications, are laid simultaneously, it is possible to reduce the pulling forces. And also to reduce the zone of structural changes in the soil around the resulting cavity and the pressure on neighboring communications compared to the traditional conical tip. Thus, it is possible to summarize that this form of a working body has the right to life and will eventually take its place in the line of working bodies for trenchless laying of cases.

\section{References}

1. Kravets S. V., Kovanko V. V., Lukianchuk O. P. Naukovi osnovy stvorennia zemleryino-yarusnykh mashyn i pidzemnorukhomykh prystroiv: monograph. Rivne: NUVHP, 2015. 322 p.

2. Kravets S., Posmitiukha O., Suponiev V. Analitychnyi sposib vyznachennia oporu zanurennia konusnoho nakonechnyka v grunt // Stroitel'stvo. Materialovedenie. Mashinostroenie. Seriya: Pod'emno-transportnye, stroitel'nye i dorozhnye mashiny i oborudovanie. 2017. Issue 103. P. 91-98. 
3. Kravets S., Posmitiukha O., Suponiev V. Vyznachennia ekvivalentnoho i optymalnoho diametriv konichnoho nakonechnyka z vystupamy dlia prokoliuvannia gruntu // Nauka i prohres transportu. Visnyk Dnipropetrovskoho natsionalnoho universytetu zaliznychnoho transportu. 2017. Issue 70. P. 89-98.

4. Allouche E. N., Ariaratnam S. T. State-Of-The-Art-Review Of No-Dig Technologies for New Installations. Pipelines, 2002. doi: http://doi.org/10.1061/40641(2002)55

5. Pridmore A., Geisbush J. Developing a Successful Specification for Horizontal Directional Drilling // Pipelines 2017. Pipelines Planning and Design Book set. 2017. P. 553-563. doi: http://doi.org/10.1061/9780784480878

6. Hastak M., Gokhale S. Decision Tool for Selecting the Most Appropriate Technology for Underground Conduit Construction // Geological Engineering: Proceedings of the 1st International Conference. New York, 2009. doi: http://doi.org/10.1115/ 1.802922.paper30

7. Bian Z. J. L. Trenchless technology underground pipes. Machinery Industry Press, 2014. 187 p.

8. Xin J. Application of Trenchless Pipeline Rehabilitation Technology // International Conference on Pipelines and Trenchless Technology. 2014. doi: http://doi.org/10.1061/9780784413821.051

9. Sterling R. L. International Technology Transfer in Tunneling and Trenchless Technology // Geological Engineering: Proceedings of the 1st International Conference. Baosong Ma, ASME, 2009. doi: http://doi.org/10.1115/1.802922.paper6

10. A Comparative Study of Soil Pressure and Deformation of Pipes Installed by the Open-Cut Method and Trenchless Technology / Tsung N. et. al. // Pipelines 2016: Out of Sight, Out of Mind, Not Out of Risk. 2016. doi: http://doi.org/10.1061/9780784479957.132

11. Najafi M., Gunnink B., Davis G. Details of Field Testing of Major Trenchless Technology Methods for Road Crossings // Geological Engineering: Proceedings of the 1st International Conference. Baosong Ma, ASME, 2009. doi: http://doi.org/10.1115/ 1.802922.paper4

12. Chehab A. G., Moor I. D. One-demensional calculation for axial pullback for axial pullback distributions in pipes during directional drilling installations. Ottava Geo, 2007. P. 1140-1154.

13. Guojun W., Xiaoming W., Han C. Trenchless Pipe-Paving in Complex Hard Stratum by Directional Drilling Technology //
Geological Engineering: Proceedings of the 1st International Baosong Ma, ASME. New York, 2009. doi: http://doi.org/ 10.1115/1.802922.paper26

14. Balesnyy S. Osobennosti protsessov staticheskogo prokola grunta // Visnik Kharkivs'kogo natsional'nogo avtomobil'nodorozhn'ogo universitetu. 2017. Issue 76. P. 138-141.

15. Khachaturyan S., Oleksin V. Issledovanie protsessa izmeneniya sostoyaniya grunta vokrug gorizontal'noy skvazhiny posle ee formirovaniya metodom staticheskogo prokola grunta // Visnik Kharkivs'kogo natsional'nogo avtomobil'no-dorozhn'ogo universitetu. 2016. Issue 73. P. 196-202.

16. Vysokoproizvoditel'nye gidropnevmaticheskie udarnye mashiny dlya prokladki inzhenernykh kommunikatsiy / Eshutkin D. N. et. al. Moscow: Stroyizdat, 1990. 171 p.

17. Tomin E. D. Bestransheynoe stroitel'stvo zakrytogo drenazha Moscow: Kolos, 1981. 240 p.

Posmituha Alexander, Senior Lecturer, Department of Applied Mechanics and Materials Science, Dnipropetrovsk National University of Railway Transport named after Academician V. Lazaryan, Dnipro, Ukraine, ORCID: http://orcid.org/0000-0002-9701-3873, e-mail: AleksandrP@3g.ua

Kravets Svyatoslav, Doctor of Technical Sciences, Professor, Department of Building, Road, Melioration, Agricultural Machinery and Equipment, National University of Water and Environmental Engineering, Rivne, Ukraine, ORCID: http://orcid.org/0000-00034063-1942,e-mail: s.v.kravets@nuтm.edu.ua

Suponyev Vladimir, PhD, Associate Professor, Department of Build and Travelling Machines, Kharkiv National Automobile and Road University, Ukraine, ORCID: http://orcid.org/0000-0001-7404-6691, e-mail:v-suponev@ukr.net

Kulazhenko Yevhenii, Assistant, Department of Bridges and Tunnels, Dnipropetrovsk National University of Railway Transport named after Academician V. Lazaryan, Dnipro, Ukraine, ORCID: http:// orcid.org/0000-0002-4529-7384, e-mail: Jaksson7777@gmail.com 